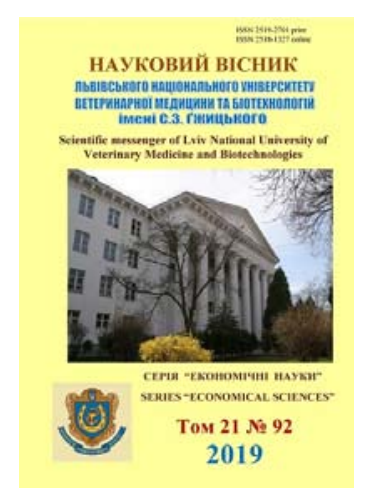

\section{Науковий вісник Дьвівського національного університету ветеринарної медицини та біотехнологій імені С.3. Гжицького. Серія: Економічні науки}

\author{
Scientific Messenger of Lviv National University \\ of Veterinary Medicine and Biotechnologies. \\ Series: Economical Sciences
}

ISSN 2519-2701 print

https://nvlvet.com.ua/index.php/economy

\title{
Transformation Lebanon`s foreign policy vector 2011-2017 y.
}

\author{
Article info \\ Received 15.02.2019 \\ Received in revised form \\ 18.03.2019 \\ Accepted 19.03.2019 \\ Stepan Gzhytskyi National \\ University of Veterinary Medicine \\ and Biotechnologies Lviv, \\ Pekarska Str., 50, Lviv, \\ 79010, Ukraine. \\ National University \\ "Lviv Polytechnic", \\ Stepan Bandera Str., 12 \\ Lviv 79013, Ukraine. \\ Tel.: +38-067-309-14-96 \\ E-mail: rpasichnyy@gmail.com
}

M.M. Dzera ${ }^{1}$, R.Y. Pasichnyy ${ }^{2}$, A.M. Ostapchuk ${ }^{2}$

${ }^{1}$ Stepan Gzhytskyi National University of Veterinary Medicine and Biotechnologies Lviv, Ukraine

${ }^{2}$ National University “Lviv Polytechnic”, Lviv, Ukraine

Dzera, M.M., Pasichnyy, R.Y., \& Ostapchuk, A.M. (2019). Transformation Lebanon`s foreign policy vector 2011-2017 y. Scientific Messenger of Lviv National University of Veterinary Medicine and Biotechnologies. Series: Economical Sciences, 21(92), 186-189. doi: $10.32718 /$ nvlvet-e9233

The place and international position of Lebanon in the world political arena today is changing and transforming under the influence of globalization. Thus, this is not deprive, but changes the vector on the international arena and does not exclude the already acquired conservative character. Prime Minister Tamam Salam, who is the executive of the President of the Republic of Lebanon, is reforming and liberalizing the law and changing the vector of foreign policy. He doing this without leaving the traditions and religious views, also without rejecting the conservative nature of foreign and domestic policies. Although Lebanon is part of the League of Arab States, which is accused of non-democracies, it has a democratic regime for a long time. Balancing the policy of the Lebanese Republic between conservatism, traditionalism, democracy and liberalization makes Lebanon a great country for analysis, since it provides an opportunity to reflect the coexistence of democracy with the stereotyped vision of the "Islamic world".

Key words: Lebanon, international programs, development, foreign policy, "Islamic world".

\section{Трансформація вектору зовнішньої політики Лівану 2011-2017 рр.}

\author{
М.М. Дзера ${ }^{1}$, Р.Я. Пасічний${ }^{2}$, А.М. Остапчук ${ }^{2}$ \\ ${ }^{1}$ Львівський національний університет ветеринарної медицини та біотехнологій імені С.3. Гжицького, \\ м. Львів, Україна \\ ${ }^{2}$ Національний університет “Львівська політехніка”, м. Львів, Украӥна
}

\begin{abstract}
Місие та міжнародне становище Лівану на світовій політичній арені на сьогоднішній день змінюється та трансформується під впливом глобалізачії. Прем'єр-міністр Тамам Салям, він ж виконувач обов 'язків Президента Ліванської Республіки, здійснює реформи та лібералізацію законодавства й змінює вектор зовнішньої політики, не відходячи від традицій та релігійних поглядів, а також не відмовляючись від консервативного характеру зовнішньої та внутрішньої політик. Хоча Ліван і входить до Ліги Арабських Держав, яку звинувачують у недемократичності, проте тривалий час у Лівані панує демократичний режим. Балансування політики Ліванської республіки між консерватизмом й традиціоналізмом та демократією й лібералізацією робить Ліван чудовою краӥною для аналізу, оскільки дає можливість відобразити співіснування демократії зі стереотипним баченням “ісламського світу”. Методологічною основою роботи став синтез системного, структурно-функціонального та компаративістського методу, в рамках системно-структурного підходу. Системно-структурний підхід надає можливість дослідити складний структурний контекст, який частково визначає можливості або перепони для реалізації зовнішньої політики, а також прослідкувати динаміку ї̈ змін. Структурно-функиіональний метод надає змогу дослідити специфіку внутрішнього устрою політичних режимів та можливостей політичних інститутів впливати на формування та реалізацію зовнішньої політики. Застосування методу аналізу документів дозволило дослідити нормативно-правову базу формування зовнішньої політики Лівану. Наукова новизна полягає у визначенні вектору трансформації зовнішньополітичного курсу Лівану 2011-2017 рр.
\end{abstract}

Ключові слова: Ліван, міжнародні програми, розвиток, зовнішня політика, “Ісламський світ”. 
На початок 2011 р., Ліван був порівняно спокійною державою, проте арабська весна додала невизначеності до політичної атмосфери країни. Суспільні збурення щодо зміни політики конфесіоналізму переросли в протистояння між прихильниками (Коаліція 8-го березня) та противниками (Коаліція 14-го березня) режиму Башара Асада в Сирії. Політичне протистояння переросло у збройні сутички, до яких пізніше доєднались радикальні ісламські угрупування, зокрема такі як: ІДІЛ, Джунд аш-Шам, а також пов'язані $з$ Аль-Каїдою Фронт ан-Нусра, Бригади Абдули Аззама. Фатх-аль-Іслам. Збройне протистояння завершилось 28 серпня 2017 р., після вдалої операції сирійських і ліванських військ, внаслідок чого бойовики радикальних ісламських угрупувань покинули територію Лівану.

Після усіх революційних змін, політичній системі Лівану притаманні наступні ознаки: за формою правління Ліван $є$ парламентською республікою; політичний режим - демократичний; законодавча влада належить парламенту, а виконавча - президенту який iіi реалізовує за допомогою кабінету міністрів; судову гілку влади представляють суди різних інстанцій.
Особливістю конституційної системи Лівану є конфесійний принцип формування органів влади та призначення на вищі державні посади, завдяки чому дотримується баланс між представниками різних релігійних громад. Відповідно конституційних засад внутрішню політику формує Палата депутатів, як законодавчий орган, а реалізовує Рада міністрів. Зовнішню політику здійснює Рада міністрів через формулювання загальних векторів зовнішньої політики, розробки законопроектів та регламентних декретів, а також приймає необхідні рішення для їх реалізації, які безпосередньо реалізовує Міністерство зовнішніх справ Лівану.

Враховуючи, що однією $з$ вимог було внесення змін до конфесійного принципу формування органів влади (зокрема і тих що формують та реалізовують зовнішню політику), проаналізуємо конституційні норми щодо впливу релігії на суспільне життя. Варто зауважити що Конституція Ліванської республіки була прийнята 23 травня 1926 року, проте в неї 8 разів вносились зміни і доповнення. На сьогоднішній день $\epsilon$ чинною Конституція зі змінами і доповненнями від 21 вересня $1990 \mathrm{p}$.

\begin{tabular}{|c|c|}
\hline Пункт Конституції & Витяг з Конституції Ліванської республіки \\
\hline $\begin{array}{l}\text { Преамбула } \\
\text { Абзац Б. }\end{array}$ & $\begin{array}{l}\text { Ліван за своєю приналежністю є частиною арабського світу і одним із засновників і активних уча- } \\
\text { сників Ліги Арабських Держав і прихильником її угод. Ліван є також активним членом Організації } \\
\text { Об’єднаних Націй, який дотримується її принципів і положень Загальної декларації прав людини. }\end{array}$ \\
\hline $\begin{array}{l}\text { Преамбула } \\
\text { Абзац } 3 .\end{array}$ & $\begin{array}{l}\text { Основним національним завданням є скасування конфесійної системи, для реалізації якої необхід- } \\
\text { но спільне втілення в життя поетапного плану. }\end{array}$ \\
\hline Стаття 9 & $\begin{array}{l}\text { Свобода совісті є абсолютною. Стосовно шанування Всевишнього Бога держава поважає всі релігії } \\
\text { і віросповідання та гарантує своїм захистом вільне відправлення релігійних культів за умови до- } \\
\text { тримання громадського порядку. Держава гарантує також всім релігійним громадам повагу до їх } \\
\text { встановлених особистих статутів і релігійних інтересів. }\end{array}$ \\
\hline Стаття 10 & $\begin{array}{l}\text { Викладання є вільним, якщо воно не порушує громадський порядок і добрі звичаї і не зачіпає гід- } \\
\text { ності існуючих в державі релігій і віросповідань. Не допускається порушення звичаїв релігійних } \\
\text { громад мати свої школи за умови дотримання ними загальних положень, встановлених державою } \\
\text { щодо народної освіти. }\end{array}$ \\
\hline Стаття 19 & $\begin{array}{l}\text { Засновується Конституційна Рада для перевірки конституційності законів та статутів... Право звер- } \\
\text { нення до Конституційної Ради щодо конституційності законів належить..., а також главам релігій- } \\
\text { них громад, які діють легально, з питань особливостей їх особистого статусу, свободи совісті, } \\
\text { відправлення релігійних культів і свободи релігійного освіти. }\end{array}$ \\
\hline Стаття 22 & $\begin{array}{l}\text { Після виборів першого складу Палати депутатів, які повинні проходити на загальнонаціональній, а } \\
\text { не на конфесійній основі, буде сформовано Сенат, в якому будуть представлені всі духовні грома- } \\
\text { ди; а сфера його повноважень буде обмежена лише питаннями, які становлять основні національні } \\
\text { інтереси. }\end{array}$ \\
\hline Стаття 24 & $\begin{array}{l}\text { До прийняття Палатою депутатів закону про вибори без конфесійного розмежування правила засі- } \\
\text { дань Палати будуть встановлюватися у відповідності до наступних норм: } \\
\text { А. Рівність між християнами і мусульманами. } \\
\text { Б. Пропорційне представництво кожної з цих двох релігійних громад. }\end{array}$ \\
\hline Стаття 95 & $\begin{array}{l}\text { Палата депутатів, обрана на основі рівного представництва мусульман і християн, повинна прийн- } \\
\text { яти необхідні рішення для забезпечення скасування конфесіоналізму у політичній сфері відповідно } \\
\text { до поетапного плану. } \\
\text { У завдання комітету входить вивчення і пропозиція засобів, які дозволять ліквідувати конфесіона- } \\
\text { лізм, і подання їх в Палату депутатів і до Ради міністрів відповідно до поетапного плану. Протягом } \\
\text { перехідного періоду: } \\
\text { А. Релігійні громади будуть представлені в структурі уряду на справедливій основі. } \\
\text { Б. Правило конфесійного представництва скасовується. Воно буде замінено спеціалізацією і ком- } \\
\text { петенцією в громадській роботі, магістратурі, військових відомствах, службі безпеки, спільних } \\
\text { публічних і економічних установах відповідно до потреб в національному масштабі, за винятком } \\
\text { посад першої категорії або аналогічного статусу. Ці посади будуть розподілятися порівну між } \\
\text { християнами і мусульманами без бронювання будь-якої посади за зазначеною громадою, з дотри- } \\
\text { манням принципу спеціалізації і компетенції. }\end{array}$ \\
\hline
\end{tabular}


Отже, про роль релігії та вплив конфесіоналізму на суспільне життя та формування органів влади в Конституції Лівану згадується у 8-ми статтях з 102-х, в яких неодноразово наголошується на рівність між християнами та мусульманами та кроки спрямовані на ліквідацію конфесіоналізму. Разом з тим варто зауважити що з моменту прийняття конституції в 1990 р. і до сьогодні, змін в основний закон щодо питання релігії внесено не було, також суспільні вимоги висловлені в період революційних подій Арабської весни також не враховані. Незважаючи на певну “зацементованість” у внутрішній політиці та прихильність до цінностей арабського світу, у зовнішній політиці Ліван $є$ активним членом ООН, та дотримується принципів і положень Загальної декларації прав людини та декларує себе як світська держава (Konstitucija Livana, 1926).

Революційні події Арабської весни 2011 р., призвели до трансформації політичної системи Лівану, відповідно дещо змістились і вектори зовнішньої політики. Не останню роль зіграло виведення Сирією військ $з$ території Лівану 20 квітня 2005 р., та припинення тридцятирічної сирійської окупації, яка чинила значний тиск на політичну систему держави. Проаналізуємо зміни у зовнішній політиці Лівану в період від 2011р до 2017 p.

Враховуючи специфічне географічне розміщення, територія Лівану до 2011 р. зазвичай розглядалась США як плацдарм або базу для вирішення конфліктних ситуацій в регіоні. Справедливо буде зауважити, що й інші світові держави і держави сусіди зазвичай розглядали Ліван з такої ж позиції, зокрема Росія, Сирія, Ізраїль, Ірак. Виходячи з цього, відносини Ліван-США були здебільшого недовірливими та мали тимчасовий, тактичний характер. Хоча це не завадило США надавати фінансову та гуманітарну допомогу ліванцям після військових конфліктів.

Згідно даних Бюро східних справ (підрозділ Державного департаменту США), станом на 2017 р., ситуація щодо взаємовідносин 3 Ліваном змінилась. США надає допомогу ліванським збройним силам та силам внутрішньої безпеки шляхом створення та навчання боєздатних сил з врахуванням складності регіону, що допомагає ліванській державі захищати свої кордони, ефективно протистояти ІДІЛ і демонструвати здатність захистити суверенітет Лівану. Американська допомога підтримує здатність ліванських збройних сил забезпечувати безпеку Лівану та захищати як національну територію, так і протистояти внутрішнім загрозам. Підтримка ліванських державних інституцій та силових структур лежить в основі зусиль США, спрямованих на збереження стабільності. Будучи основним партнером з безпеки, Сполучені Штати надали Лівану допомоги на суму понад 1,7 млрд. доларів США на реалізацію проектів з питань безпеки. Завдяки наданню літаків з фіксованим та обертальним крилом, боєприпасів, транспортних засобів та пов'язаних $з$ ними підготовки ліванські збройні сили значно збільшили свій потенціал як бойову силу проти насильницьких екстремістів. Крім того, допомога США посилює зусилля Ліванської сили внутрішньої безпеки щодо запобігання, протидії та реагування на кримінальні та терористичні загрози та їх основні причини, забезпечення і захист території та населення Лівану, заборонити заборону на випадок розповсюдження зброї масового знищення та розширити норми закону по всій країні. Окрім допомоги у силовому секторі, Сполучені Штати виділили близько 1,8 мільярдів доларів на гуманітарну допомогу для Лівану 3 моменту початку Сирійської кризи.

Допомога Лівану в економічному секторі та правосудді полягає в підтримці програм, які сприяють працевлаштуванню, збільшенню робочих місць та продуктивності праці, належному врядуванні, соціальній єдності та економічному зростанню. Допомога також спрямовується на підтримку доступу до чистої води та вдосконалення освітніх послуг для ліванських громад, особливо тих, на які сильно впливає приплив сирійських біженців. Протягом останніх десяти років Сполучені Штати вклали понад 170 мільйонів доларів в базові освітні програми та понад 160 мільйонів доларів у програми вищої освіти.

У Лівані найвища кількість біженців на душу населення в світі, де зареєстровано більше одного мільйона зареєстрованих біженців з Сирії, від 170000 до 270000 постійно зареєстрованих палестинців, зареєстрованих в ООН, та понад 20000 іракських та інших біженців. 3 початку кризи в Сирії гуманітарна допомога США в Лівані відповідає критичним потребам сирійських біженців та громадських організацій, включаючи продовольство, притулок, медичну допомогу, чисту воду та санітарні послуги, освіту та психосоціальну підтримку. Як бачимо, у взаємовідносинах США-Ліван відбулись кардинальні зміни, зокрема Ліван був замінений Єменом в списках країн, які не вселяють довіри, що вказує на пом'якшення політики з боку США.

Взаємовідносини Свропейський Союз-Ліван, почали покращуватися після подій Арабської весни Це виражається через впровадження Ліваном реформ спрямованих на лібералізацію, світськість законодавства та модернізацію судової системи які СС активно фінансує. Починаючи 32011 р. Міністерство юстиції Лівану розпочало кампанію, спрямовану на підтримку скасування смертної кари як найвищої міри покарання та заміни іiі на довічне ув'язнення, також було створено підрозділ, відповідальний за інформатизацію Міністерства юстиції та судів. Ліван створив одне 3 найбільш відкритих та різнопланових медіасередовищ на Близькому Сході. Ліберальне законодавство дозволяє організаціям громадянського суспільства в Лівані почувати себе досить вільно. У сфері безпеки СС продовжував допомагати Лівану очищати країну від касетних боєприпасів та боєприпасів що не вибухнули. Завдяки проектам, що фінансуються $\mathrm{CC}$, було очищено 2,3 мільйони квадратних метрів землі.

Починаючи з 2017 р. взаємовідносини вийшли на новий якісний рівень. Основним фінансовим інструментом ЄС до 2020 року є Свропейський інструмент сусідства, в рамках якого допомога Лівану буде зосереджена на узгоджених пріоритетах партнерства, зокрема: безпека та боротьба з тероризмом, верховенство права, сприяння економічному зростанню та працевлаштування, міграція та мобільність. Певні 
тематичні програми допомоги - наприклад, права людини та розвиток інститутів громадянського суспільства -фінансуються окремо. Незважаючи на підтримку інститутів громадянського суспільства, ЄС віддає перевагу роботі з національними установами та місцевими органами влади, оскільки допомога передбачає прогнозування бажаного ефекту, звітність та контроль. Фінансові пакети формуються та надаються постійно та дозволяють підтримувати розвиток та реформи на належному рівні відповідно до плану дій. В першу чергу - СС надає підтримку уряду Лівану, муніципалітетам та заходам спрямованим на реформу судів, в другу - підтримка малих та середніх підприємств, в третю - підтримка заходів спрямованих на кризові виклики, відновлення та стабілізацію наслідків. Гуманітарна допомога надається через Генеральну дирекцію Європейської Комісії 3 гуманітарної допомоги та цивільного захисту і є основним інструментом, який сприяє стабільності. Зокрема ЄС є найбільшим донором в напрямку протидії мінній загрозі, включаючи підтримку Ліванського протимінного центру. СС також скеровує допомогу на захист прав та покращення умов життя палестинських біженців в Лівані, підтримка в основному спрямовується через Близькосхідне Агентство Організації Об'єднаних Націй по сприянню та роботі з палестинськими біженцями, а також через неурядові організації.

Зовнішня політика держави є продовженням внутрішньої політики, яка грунтується на соціальнополітичному дискурсі який панує в суспільстві. Зовнішня політика Лівану стосовно Ізраїлю не є виключенням. Традиційно більшість мусульманських країн Близькосхідного регіону висловлюють сильні, негативні погляди щодо євреїв, відповідно ставлення до Ізраїлю у громадян Лівану було також негативним. Дослідження Pew Research Center, у 2008 році, виявило що 97\% ліванців негативно ставились до євреїв. Оглядове дослідження цієї ж організації, проведене в 2011 році підтвердило попередні результати опитування, лише 3\% ліванських громадян зазначили позитивне/нейтральне ставлення до євреїв. Проте ліванська влада не $є$ критичнонегативною щодо Ізраїлю і намагаються не загострювати взаємовідносин. Яскравим прикладом є заміна анонсованої Ліваном смертної кари для майже 100 осіб, підозрюваних у шпигунстві в користь Ізраїлю, арештованих в період 3 квітня 2009 року по липень 2010 року. На сьогоднішній день, демократичні трансформації торкнулися правоохоронної та судової системи, які значно гуманізувались, внаслідок чого, де-факто, було скасовано смертну кару та замінено іiі на довічне ув'язнення, як максимальне покарання. Значний вплив на політичне та суспільне життя здійснює Ісламська Республіка Іран через свою ліванську прокуратуру “Хезболлах" та намагається наповнивши регіон зброєю перетворити Ліван у чергову точку конфлікту з Ізраїлем. Сучасна влада
Лівану опирається цим тенденціям та докладає усіх зусиль недопущення конфлікту, у відповідь Ізраїль обмежив політику щодо атак на повітряні судна Лівану у відповідь. Як бачимо взаємовідносини Лівану та Ізраїлю $\epsilon$ складними, але на сучасному етапі їх намагаються стабілізувати і спрямувати в конструктивне русло (Rejting stran mira po urovnju demokratii informacija ob issledovanii, 2006).

Проаналізувавши трансформацію зовнішньополітичного вектору Лівану в період 2011-2017 рр., можемо відмітити його прозахідність, лібералізацію, намагання стабілізувати ситуацію не тільки в середині держави, але й в регіоні шляхом налагодження мирних стосунків з сусідами. Ліван уникає конфлікту 3 Ізраїлем та почав співпрацю з США, результатом чого стало виключення Лівану зі списку країн, яким не варто довіряти. Співпраця з Свропейського Союзу та Лівану відбувається в рамках Угоди про асоціацію між двома країнами, яка діє з квітня 2006 року. Це партнерство базується на спільних цінностях та інтересах, регулярному політичному, безпековому, економічному та соціальному діалозі. СС прагне підтримувати демократію, належне врядування, соціальну інтеграцію, освіту та сталий розвиток в Лівані. 3 2011 р. "Європейський інструмент сусідства" став основним фінансовим інструментом СС на період 2014-2020 роки та доповнив політичну Угоду про асоціацію, яка дієз квітня 2006 р. Це партнерство базувалось на спільних цінностях та інтересах, регулярному політичному, безпековому, економічному та соціальному діалозі. Щодо співпраці в 2017-2020 pp., допомога СС Лівану була та буде зосереджена на узгоджених пріоритетах партнерства: безпека та боротьба 3 тероризмом; управління та верховенство права; сприяння економічному зростанню та працевлаштуванню; міграція та мобільність.

Отже, підводячи підсумок бачимо, що збереження напрямку орієнтованого на демократичні цінності дає можливість Лівану поширювати та розвивати співпрацю із Заходом. Грамотне балансування між Арабським світом $з$ його консервативними цінностями та пошук компромісу 3 демократичними цінностями Західної цивілізації, дають можливість розширити та розвинути в цих країнах не тільки економічну, а й політичну та соціальну сфери суспільного життя i зберегти цілісність держави.

\section{References}

Rejting stran mira po urovnju demokratii informacija ob issledovanii (2006). [Elektronnij resurs]. Rezhim dostupu do resursu: https://gtmarket.ru/ratings/ democracy-index/info (in Russian).

Konstitucija Livana (1926). [Elektronnij resurs]. Rezhim dostupu do resursu: https://worldconstitutions.ru/ $? \mathrm{p}=90 \&$ attempt $=2$ (in Russian). 